\title{
Evaluasi Sistem Pengendalian Internal Terhadap Prosedur Pemberian Kredit pada PT. Bank Central Asia, Tbk Cabang KCU Kalimalang
}

\author{
Winta \\ Universitas Trilogi \\ Wintataa25@gmail.com \\ Khoirina Farina \\ Universitas Trilogi \\ khoirina@trilogi.ac.id
}

\begin{abstract}
Abstrak Prosedur pemberian kredit yang masih kurang baik merupakan dampak terjadinya kredit macet atau kredit bermasalah yang tentunya menghambat kelancaran usaha bank serta menyebabkan krisis kepercayaan dari masyarakat. Sehingga diperlukan sistem pengendalian internal untuk menilai pelaksanaan serta mengetahui kebijakan manajemen bank dalam proses pemberian kredit. Tujuan riset adalah untuk mengetahui prosedur pemberian kredit dan penerapan sistem pengendalian internal PT Bank Central Asia Tbk KCU Kalimalang. Metode penelitian yang digunakan adalah deskriptif kualitatif dengan melakukan survei lapangan seperti wawancara, observasi dan dokumentasi. Hasil penelitian menunjukkan bahwa implementasi prosedur pemberian kredit telah sesuai dengan standar pemberian kredit. Implementasi sistem pengendalian internal pada pemberian kredit pada PT Bank Central Asia Tbk KCU Kalimalang telah memenuhi standar pengendalian internal Committee of Sponsoring Organizations of the Treadway Commission (COSO), namun masih terdapat kelemahan, yakni terdapat pada komponen aktivitas pengendalian yaitu account officer merangkap beberapa fungsi mulai dari pemasaran, analisa kredit hingga pemantauan.
\end{abstract}

Kata Kunci Prosedur Kredit, Kredit Macet, Sistem Pengendalian Internal

\section{PENDAHULUAN}

Bank merupakan lembaga intermediasi keuangan (financial intermediary) antara pihak-pihak yang membutuhkan dana (deficit unit), dan lembaga yang berorientasi pada bisnis yang tentunya dapat memperlancar pembayarannya. Bank juga berfungsi sebagai menghimpun dana masyarakat dalam bentuk tabungan dan lainnya. Selain itu kegiatan bank adalah memberikan kredit kepada masyarakat. Menurut (Kasmir, 2014) kredit merupakan kegiatan usaha bank yang bertujuan memperoleh keuangan dengan cara mendistribusikan dana kepada masyarakat karena sumber utama pendapatan bank berasal dari pemberian kredit yaitu dalam bentuk pendapatan bunga kredit. Sangat penting adanya sistem pengendalian pada proses pemberiaan kredit dengan tujuan bebas dari segala macam risiko dan kecurangan-kecurangan yang mungkin terjadi. Penyebab kredit macet bisa disebabkan oleh pihak debitur maupun kreditur. Adanya pengaruh dari calon debitur yang bekerja sama dengan pihak pegawai bank menyebabkan debitur mendapatkan hasil kredit 
sesuai harapannya, yaitu memperoleh kredit yang lebih besar dari kebutuhan dan ini menyebabkan timbulnya kredit macet. Risiko kredit yang bermasalah ini dapat diatasi dengan adanya pengendalian internal yang efektif.

Dengan demikian maka bank perlu menerapkan suatu prosedur pemberian kredit untuk nasabah yang ingin mengajukan kredit. Prosedur yang dibuat tentunya harus memiliki standar perbankan dan harus sesuai dengan sistem pengendalian internal yang diterapkan oleh bank. Dalam hal pemberian kredit bank juga harus memperhatikan prosedur dan pengendalian internal kredit sesuai prinsip 5C. Menurut (Kasmir, 2014) Prinsip 5C yaitu watak (Character), kemampuan (Capacity), modal (Capital), jaminan (Collateral), kondisi ekonomi (Condition of Economy). Prinsip tersebut sangat penting dan tidak boleh dihilangkan salah satu penilaiannya karena prinsip ini menjadi pertimbangan bank dalam memberikan persetujuan pemberian kredit kepada nasabah. Dengan adanya penerapan sistem pengendalian internal pada saat pemberian kredit tentunya mampu meminimalisir terjadinya kredit bermasalah atau macet serta lepas dari segala macam risiko dan kecurangan dan manipulasi yang mungkin terjadi. Dalam pelaksanaan pengendalian internal tersebut dilakukan pengawasan kepada nasabah dan dilakukan pemantauan apakah ada nasabah yang tidak dapat mengembalikan kredit dan akan ditemukan penyebab nasabah tersebut tidak dapat mengembalikan kreditnya atau disebut kredit macet dan tentunya ditemukan solusi dari kendala tersebut. Oleh Karena itu penulis tertarik untuk mengevaluasi prosedur bank dalam pemberian kredit dan pengendalian internal bank pada proses pemberian kredit. Rumusan masalah dalam penelitian ini yaitu bagaimana prosedur pemberian kredit di PT Bank Central Asia Tbk KCU Kalimalang dan apakah sistem pengendalian internal dalam pemberian kredit sudah sesuai dengan standar COSO.

\section{LANDASAN TEORI}

Menurut (Coso, 2013) sistem pengendalian internal merupakan suatu proses yang melibatkan dewan komisaris, manajemen, dan personil lain, yang dirancang untuk memberikan keyakinan memadai tentang pencapaian tiga tujuan yaitu efektivitas dan efisiensi operasi, keandalan pelaporan keuangan, kepatuhan terhadap hukum dan peraturan yang berlaku. Menurut Arens \& Mark.S. Beaslev (2008), sistem pengendalian internal merupakan suatu kebijakan dan prosedur yang disusun untuk memberikan manajemen dapat menentukan keputusan yang tepat sehingga perusahaan dapat mencapai tujuan dan sasarannya. Tujuan yang dimaksud tersebut berupa reliabilitas, pelaporan keuangan, efisiensi dan efektivitas operasi, ketaatan pada hokum dan peraturan.

. Menurut (Coso, 2013) terdapat lima komponen pada sistem pengendalian internal, yakni lingkungan pengendalian (control environment), penilaian risiko (risk assessment), aktivitas pengendalian (control activities), informasi dan komunikasi (information and communication), aktivitas pemantauan (monitoring activities).

Hasil penelitian Mohammad Muzamil (2015), menjelaskan bahwa penerapan sistem pengendalian internal bank BRI KCP Unit Karang Paci belum sejalan, yaitu masih terdapat fungsi ganda diantaranya pada fungsi bagian survei dan analisa kredit namun hal tersebut bertujuan untuk menekan risiko kredit bermasalah di BRI KCP Unit Karang Paci.

.Penelitian Ismy Sentya Kartika, Alis Rasyidi, dan Mahsina (2015), hasil risetnya menunjukkan pelaksanaan audit internal di Bank BTN Surabaya sudah sejalan dengan pedoman pelaksanaan audit internal yang telah diatur oleh kantor pusat. Komponenkomponen pengendalian internal COSO juga sudah diterapkan dengan sangat memadai. 


\section{METODOLOGI PENELITIAN}

Penelitian ini menggunakan pendekatan deskriptif kualitatif dengan studi kasus pada PT Bank Central Asia Tbk KCU Kalimalang. Riset ini menggunakan data primer dan data sekunder. Data primer, yaitu data penelitian yang diperoleh secara langsung dari sumbernya melalui wawancara. Sedangkan data sekunder berupa dokumen-dokumen yang mendukung riset berupa profil, sejarah, visi dan misi PT Bank Central Asia Tbk dan data pustaka lain yang terkait dengan pengendalian internal. Metode pengumpulan data dilakukan dengan cara mendatangi secara langsung objek penelitian yakni PT Bank Central Asia Tbk KCU Kalimalang, dan peneliti melakukan wawancara dengan pihak-pihak yang terkait.

\section{HASIL PENELITIAN}

Berdasarkan hasil observasi penelitian, maka evaluasi pengendalian internal yang akan dibahas adalah prosedur pemberian kredit dan penerapan sistem pengendalian internal dengan menggunakan standar Committee of Sponsoring Organizations of the Treadway Commission (COSO) pada PT Bank Central Asia Tbk KCU Kalimalang. Penelitian ini fokus pada prosedur pemberian Kredit Usaha Kecil (KUK) yang merupakan salah satu jenis kredit modal kerja dengan plafon kredit maksimal Rp 500 juta.

Prosedur Pemberian Kredit PT Bank Central Asia Tbk terdiri dari lima tahapan:

1. Tahap prosedur pengajuan permohonan kredit oleh nasabah. Prosedur pengajuan kredit usaha kecil (KUK) di PT Bank Central Asia Tbk KCU Kalimalang adalah sebagai berikut:

a. Nasabah yang mengajukan permohonan kredit mengisi surat permohonan kredit, dan melengkapi dokumen yang dibutuhkan, lalu diserahkan ke pihak account officer yang bertugas menangani permintaan kredit tersebut. Data dokumen yang dibutuhkann dalam permohonan kredit sebagai berikut

1. Nasabah perorangan: melampirkan KTP suami dan istri, surat nikah, Kartu Keluarga (KK), Nomor Pokok Wajib Pajak (NPWP), Surat Izin Usaha Perorangan (SIUP), Tanda Dagang Perorangan (TDP), dan rekening koran empat bulan terakhir atau lebih.

2. Nasabah perusahaan: KTP pengurus, KTP Komisaris Direktur, Nomor Pokok Wajib Pajak (NPWP) Direktur, Tanda Dagang Perorangan (TDP), Akta Kementerian Hukum dan Ham, Akta Pendirian PT/Badan Usaha, Akta Perubahan Terakhir, Nomor Pokok Wajib Pajak (NPWP) PT/Badan Usaha, rekening koran empat bulan terakhir.

b. Semua dokumen nasabah di review kembali kelengkapannya dan apabila terdapat dokumen yang tidak lengkap, akan dikembalikan kepada calon debitur untuk dilengkapi.

c. Selanjutnya account officer akan mengidentifikasi karakter calon debitur dengan mempelajari kebutuhan dari calon debitur dengan cara menjalin hubungan serta mengumpulkan informasi calon debitur yang akan melakukan kredit.

2. Tahap prosedur dalam menganalisa Kredit Usaha Kecil (KUK) di PT Bank Central Asia Tbk KCU Kalimalang yaitu sebagai berikut :

a. Account officer, dengan mengandalkan prinsip 5C, yakni character, capacity, capital, collateral dan condition akan mengevaluasi kredit yang diajukan oleh debitur. 
Kegiatan ini dijalankan dengan cara melakukan kunjungan ke tempat usaha nasabah, melakukan wawancara serta menilai kelayakan lokasi tempat tersebut berdasarkan kredit yang akan diberikan. Kunjungan tersebut dilakukan bersama dengan tim penilai agunan yang ditunjuk oleh pihak bank.

b. Account officer kemudian membuat berita acara pemeriksaan (BAP) dan menyusun laporan analisa kredit, selanjutnya dilaporkan kepada kepala pengembangan bisnis cabang untuk dianalisa lebih lanjut. Apabila terdapat dokumen atau data-data debitur yang tidak komplit atau tidak sesuai dengan peraturan kredit yang berlaku, maka permohonan kredit akan ditolak. Informasi penolakan atas kredit tersebut akan disampaikan oleh account officer yang bertugas memberikan surat kepada nasabah.

c. Dokumen yang telah dianalisa tersebut akan diperiksa kembali oleh kepala kantor cabang utama dan akan diproses oleh pihak account officer dengan cara melakukan analisa risiko kredit menggunakan aplikasi ICOS.

d. Setelah analisa kredit dilakukan, proses selanjutnya adalah petugas atau karyawan bank, yakni account officer akan mengisi surat yang menyatakan persetujuan pemberian kredit, surat tersebut ditandatangani oleh Kepala Kantor Cabang Utama dan account officer. Kemudian surat tersebut (Surat Persetujuan Pemberian Kredit (SPPK) yang telah ditandatangan tersebut akan diberikan kepada pihak administrasi kredit yang bertugas memverifikasi kesesuaian data dengan dokumen asli calon debitur. Selanjutnya dokumen akan disimpan sebagai arsip bersama dengan SPPK tersebut. Dokumen disimpan kedalam dosir. Dosir merupakan arsip yang berisi datadata nasabah yang disimpan oleh account officer.

Pada tahapan ini analisa kredit dan penilaian risiko kredit menggunakan sistem aplikasi bernama Integrated Credit Origination System (ICOS). Hasil menganalisa dengan 5C tersebut, selanjutnya data informasi dan dokumen berkaitan dengan calon debitur akan di input ke dalam aplikasi ICOS oleh petugas atau account officer. Aplikasi ICOS ini dibuat untuk mendukung proses persetujuan kredit. Pada sistem permohonan Kredit Usaha Kecil (KUK) terdapat ketentuan tanda warna yang menjadi pertimbangan dari segi risiko kredit tersebut apakah kredit diterima atau ditolak, tanda warna tersebut adalah sebagai berikut

1. Warna putih (White) menunjukkan kredit dapat diterima dan disetujui.

2. Warna hitam (Black) menunjukkan kredit tidak dapat diterima atau ditolak.

Hasil pengolahan dari sistem ICOS ini akan diperiksa kembali oleh Kepala Pengembangan Bisnis Cabang (KPBC). Setiap pejabat memiliki tanggung jawab berbeda tergantung pada hasil jenis warna yang muncul dari system aplikasi ICOS. Kepala Kantor Cabang akan memberi keputuan bahwa pemberian keredit disetujui jika yang muncul dari sistem ICOS berwarna putih. Dan apabila hasil dari aplikasi ICOS yang keluar berwarna hitam atau black maka secara sistem permohonan kredit tersebut otomatis ditolak.

3. Tahap prosedur keputusan kredit usaha kecil (KUK) di PT Bank Central Asia Tbk KCU Kalimalang berdasarkan analisa kredit yang telah dilakukan, Pada tahapan ini pejabat pemutus kredit memiliki wewenang memberi keputusan permohonan kredit tersebut layak atau tidak layak untuk diberikan kredit dengan beberapa persyaratan tertentu. Persetujuan pemberian keputusan kredit dilaksanakan oleh pejabat yang berwenang. 
a. Kredit yang diberikan sampai dengan satu miliar dapat disetujui oleh Kepala Pengembangan Bisnis Cabang (KPBC).

b. Kredit yang diberikan mulai dari satu miliar sampai dengan tiga miliar dapat disetujui oleh Kepala Kantor Cabang Utama.

c. Kredit yang diberikan lebih dari tiga miliar dapat disetujui oleh Kepala Kantor Wilayah.

Untuk keputusan kredit usaha kecil (KUK) dengan plafon kredit maksimal Rp. 500 juta disetujui oleh Kepala Pengembangan Bisnis Cabang (KPBC). Setiap keputusan yang diberikan harus diperiksa kembali oleh Kepala Kantor Cabang Utama.

4. Tahap prosedur perjanjian Kredit Usaha Kecil (KUK) di PT Bank Central Asia Tbk KCU Kalimalang yaitu :

a. Administrasi kredit harus memahami keputusan kredit, dimulai dari fasilitas kredit yang diberikan, syarat - syarat yang harus dipahami oleh calon debitur mengenai keputusan kredit, kemudian akan dipaparkan ke dalam surat kontrak.

b. Administrasi kredit melakukan aktivitas membuat kontrak kredit dan mengontak pihak notaris yang ditunjuk oleh pihak bank untuk membuat kontrak kredit dan akta perjanjian hak tanggungan.

c. Pihak debitur dan administrasi kredit melakukan penandatanganan surat kontrak di kantor notaris tersebut.

5. Tahap prosedur pencairan dan pelunasan Kredit Usaha Kecil (KUK) di PT Bank Central Asia Tbk KCU Kalimalang yaitu sebagai berikut :

a. Setelah surat kontrak ditandatangani oleh pihak debitur, selanjutnya pihak administrasi kredit menginformasikan ke kantor pusat PT Bank Central Asia Tbk bahwa telah terjadi perjanjian kredit dengan debitur, proses berikutnya adalah pencairan dana kredit kepada rekening debitur yang bersangkutan.

b. Proses pencairan dana akan dilakukan debitur melalui teller dengan memakai slip penarikan.

c. Penyetoran dana yang dilakukan debitur melalui teller dengan memakai slip setoran.

d. Apabila debitur yang ingin melakukan pelunasan kredit, maka debitur atau nasabah harus mengisi formulir dan menyerahkan bukti pelunasan, dana pada rekening debitur akan dikurangi sebesar jumlah dana yang disetor oleh debitur. 
Berikut adalah flowchart prosedur pemberian kredit usaha kecil (KUK) pada PT Bank Central Asia Tbk KCU Kalimalang

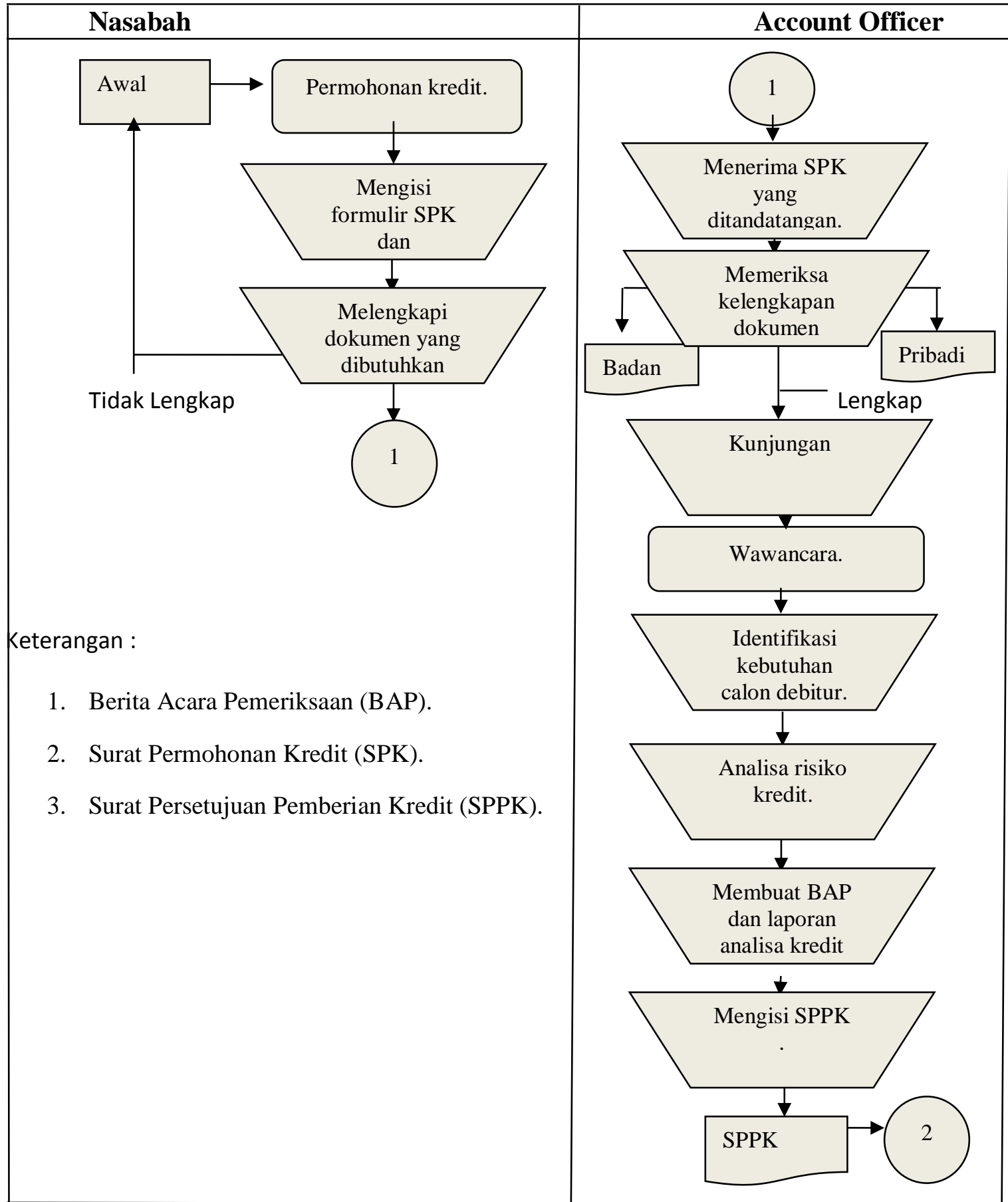

Gambar 1. Flowchart prosedur pemberian kredit PT Bank Central Asia Tbk. 
E-ISSN : 2599-3410 | P-ISSN : 2614-3259

DOI : https://doi.org/10.36778/jesya.v4i1.292

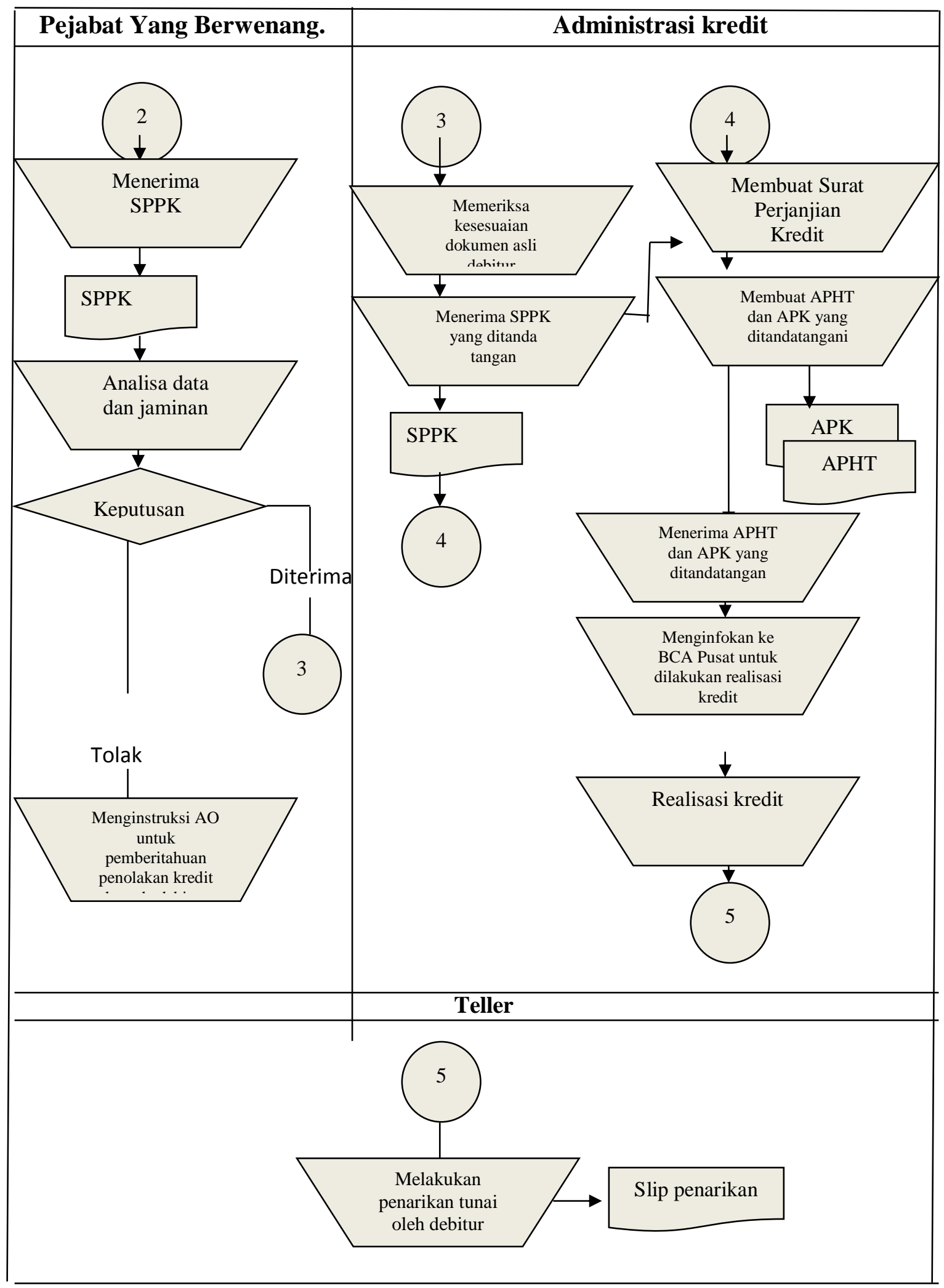

Gambar 2 Flowchart lanjutan prosedur pemberian kredit PT Bank Central Asia Tbk. 


\section{Sistem Pengendalian Internal pada Prosedur Pemberian Kredit di PT Bank Central Asia Tbk KCU Kalimalang.}

1. Lingkungan Pengendalian (Control Environment).

Lingkungan pengendalian dapat diuraikan menjadi beberapa komponen menurut (Coso, 2013) yaitu :

a. Integritas dan nilai etika

Dalam melakukan kunjungan dalam proses pemberian kredit harus menjunjung tinggi nilai kejujuran seperti tidak menerima penyuapan dalam bentuk apapun antara debitur dengan pihak bank. PT Bank Central Asia Tbk telah memiliki buku pedoman (manual of operation) dalam pemberian kredit yang lengkap. Buku pedoman ini juga sudah memadai untuk pemberian kredit.

b. Melaksanakan Tanggung Jawab Pengawasan

Peran pejabat yang berwenang dalam proses pemberian kredit. Setelah kredit disetujui proses berikutnya akan dilakukan review terhadap kinerja pemberian kredit tersebut. Dan sebelum kredit tersebut sampai ke pemutus kredit, kredit juga harus dianalisis terlebih dahulu oleh pihak account officer, lalu kemudian baru dianalisa kembali oleh Kepala Pengembangan Bisnis Cabang (KPBC), sehingga permohonan kredit tentunya harus melewati beberapa tahapan sebelum diberikan kepada debitur. Kemudian komite audit akan mengevaluasi kinerja dan juga mengaudit pemberian kredit tersebut.

c. Menetapkan struktur, wewenang dan tanggung jawab

Struktur organisasi di PT Bank Central Asia Tbk KCU Kalimalang tentunya sudah dirancang dengan tujuan agar perencanaan, pelaksanaan, pengendalian kegiatan operasional dapat berjalan dengan baik. Hasil observasi menunjukkan bahwa PT Bank Central Asia Tbk telah memiliki struktur organisasi yang baik dan juga pemisahan tugas sesuai divisinya masing-masing. Adapun wewenang dan tanggung jawab yang dijalankan di PT Bank Central Asia Tbk KCU Kalimalang sudah baik, dilihat dari penetapan tugas dan tanggung jawab yang jelas dan sesuai dalam proses pemberian kredit, mulai dari account officer yang bertugas sebagai marketing, dan menganalisis kredit, melakukan monitoring hingga kredit diberikan ke debitur. Administrasi kredit yang memiliki tanggung jawab dalam proses akad kredit hingga realisasi kredit. Penilai agunan memiliki tugas memberikan penilaian atas jaminan atau agunan yang diserahkan oleh debitur. Kepala Pengembangan Bisnis Cabang bertugas mengambil keputusan untuk menyetujui atau tidaknya permohonan kredit yang diusulkan oleh calon debitur. Kepala Kantor Cabang Utama bertugas untuk mereview kembali hasil keputusan kredit yang dilakukan. Sedangkan teller dalam proses pemberian kredit modal kerja bertugas memberikan pelayanan atas aktivitas pengambilan dana oleh nasabah dan menerima penyetoran dana oleh nasabah.

d. Menunjukkan komitmen terhadap kompetensi.

PT Bank Central Asia Tbk KCU Kalimalang berkomitmen untuk terus memberikan pelayanan perbankan terbaik untuk nasabah serta memberikan kepercayaan kepada nasabah. Salah satunya memberikan layanan pemberian kredit kepada nasabah untuk mempermudah nasabah dalam usaha atau modal. PT Bank Central Asia Tbk dalam mewujudkan komitmen terhadap kompetensi dilihat dari sumber daya manusia yang dimiliki kemudian dikembangkan keterampilannya dalam bekerja untuk meningkatkan kualitas sumber daya manusia serta kompetensinya. Dengan 
demikian yang memiliki tanggung jawab dalam proses pemberian kredit adalah account officer yaitu sebagai analisa kredit. Dalam merekrut karyawan yakni account officer, PT Bank Central Asia Tbk memberikan pelatihan sebanyak dua kali. Tujuan adanya pelatihan tersebut agar para account officer dapat menganalisis dengan baik kredit untuk debitur.

e. Mendorong akuntabilitas.

PT Bank Central Asia Tbk KCU Kalimalang dinilai sudah sesuai dalam komponen ini, untuk account officer diperlukan untuk mengikuti pelatihan agar kompetensi dalam menganalisis kredit dapat berkembang dan meningkatkan prestasi serta kinerjanya di perusahaan. Dengan adanya kebijakan tersebut menambah semangat kerja bagi karyawan untuk terus bekerja, selain itu dengan adanya penghargaan yang diberikan kepada karyawan yang memiliki keterampilan untuk berkompetisi satu sama lain.

2.Penilaian Risiko (Risk Assessment).

Penilaian risiko kredit yang ada di PT Bank Central Asia Tbk KCU Kalimalang dilakukan dengan dua cara metode diantaranya kualitatif dan kuantitatif. Untuk metode kualitatif penilaian risiko kredit dapat menggunakan prinsip analisis 5C (character, capacity, capital, collateral, dan condition of economy) dimana semua komponen didalamnya sangat penting dan tidak boleh dihilangkan.

Sedangkan metode kuantitatif penilaian risiko kredit diukur menggunakan rasio-rasio seperti Liquidity Ratio, Return on Investment (ROI), Return on Asset (ROA), Profitability Ratio dan juga menggunakan laporan keuangan. Untuk sistem penilaian risiko di PT Bank Central Asia Tbk telah menggunakan aplikasi sehingga lebih efektif dan memberikan kemudahan bagi pemutusan kredit. Pada saat proses penandatanganan kredit juga harus disaksikan oleh pihak yang berwenang untuk meminimalisir manipulasi tanda tangan. Untuk hasil analisa 5C yang telah dilakukan account officer akan diinput ke dalam aplikasi bernama ICOS beserta dokumen yang dibutuhkan oleh debitur. Di dalam aplikasi tersebut terdapat data-data nasabah yang secara otomatis mempermudah dalam perhitungan risiko kredit. Sehingga aplikasi tersebut tentunya dapat mempermudah sistem kerja account officer dalam menghitung penilaian risiko kredit atau credit risk rating yang telah dievaluasi sebelumnya. Aplikasi ini dirancang untuk membantu proses persetujuan kredit.

Dari hasil informasi yang telah diberikan oleh pihak account officer, sistem permohonan kredit di PT Bank Central Asia Tbk KCU Kalimalang dilakukan melalui menetapkan salah satu kode warna untuk mempertimbangkan dari risiko kredit dan memberikan hasil keputusan mengenai kredit tersebut. Kode warna kredit tersebut yaitu

a. Putih (White) yang artinya risiko kredit dapat diterima dan disetujui.

b. Hitam (Black) yang artinya risiko kredit tidak dapat diterima dan ditolak.

Setelah itu, hasil analisa akan di review oleh Kepala Pengembangan Bisnis Cabang (KPBC). Dari kedua warna tersebut masing-masing pejabat mempunyai wewenang yang berbeda, tergantung dari hasil warna yang dihasilkan. Untuk hasil warna white maka Kepala Kantor Cabang Utama dan Kepala Kantor Wilayah akan memberikan keputusan dari sisi bisnis nasabah. Dan apabila hasil warna black maka secara sistem ditolak. Dengan demikian dalam pemutusan kredit dilakukan minimal oleh dua orang, dan tidak dapat dilakukan hanya dengan satu orang saja. Proses persetujuan kredit itu sendiri dilakukan oleh beberapa pejabat bank untuk dilakukan review terlebih dahulu sehingga dapat dengan mudah mendeteksi permasalahan-permasalahan yang muncul. 


\section{Aktivitas Pengendalian (Control Activities)}

Aktivitas pengendalian dalam hal ini merupakan suatu kebijakan dan prosedur yang dibuat untuk memastikan semua arahan dari pimpinan dapat dilaksanakan dengan baik. Dengan ini aktivitas pengendalian yang dilakukan oleh PT Bank Central Asia Tbk KCU Kalimalang dalam proses pemberian kredit adalah :

a. Pada proses pemberian kredit diberikan otorisasi yang dilakukan oleh pejabatpejabat yang berwenang. Proses otorisasi dimulai dari pejabat yang berwenang melakukan review kembali atas permohonan kredit oleh debitur yang telah dianalisa oleh account officer. Pejabaat seperti kepala kantor wilayah, kepala kantor cabang, kepala kantor cabang utama, kepala pengembangan bisnis cabang dan senior account officer memiliki wewenang untuk memberikan kepetusan kredit.

b. Dalam hal pemisahan fungsi di PT Bank Central Asia Tbk KCU Kalimalang sudah cukup baik dilakukan dalam pemberian kredit. Pemisahan fungsi yang dimaksud yaitu proses pemberian kredit dari pemasaran, analisa hingga pemantauan kredit dilakukan oleh account officer. Pejabat seperti kepala kantor cabang atau kepala pengembangan bisnis cabang memiliki wewenang untuk memberikan keputusan kredit. Setelah kredit disetujui maka semua dokumen-dokumen dan hasil pengolahan akan diinput oleh bagian administrasi kredit atau account officer. Pencairan dana kredit dapat dilakukan di teller.

c. Pada proses verifikasi dilihat dari mulai permohonan kredit dari debitur, kemudian pengumpulan informasi dari data dokumen yang berhubungan dengan analisis kredit akan didokumentasikan oleh bagian administrasi kredit. Fungsi dari bagian administrasi kredit ini memeriksa kembali kelengkapan data dokumen yang berhubungan dengan pemberian kredit sudah sesuai dengan prosedur internal perusahaan. Dan juga memastikan data yang diinput pada aplikasi ICOS sudah akurat.

d. Di PT Bank Central Asia Tbk KCU Kalimalang sudah memiliki pengalaman yang memadai dalam fasilitas akses ke program komputer dan pengarsipan data. Dilihat dari sistem pengamanan komputer perusahaan yang memiliki akses yang hanya bisa diakses di komputer perusahaan saja. Dan juga dilihat dari pengarsipan dokumen kredit yang telah didokumentasikan dengan lengkap dan disimpan aman oleh bagian administrasi kredit. Untuk salinan dokumen penting tersebut akan disimpan dan diarsip oleh account officer dalam bentuk dosir. Dosir adalah sekumpulan dokumen yang berkaitan dengan proses kredit dan analisa. Semua dokumen dalam dosir akan dibandingkan terlebih dahulu dengan aslinya. Setiap account officer memegang dosir masing-masing sesuai dengan debiturnya masingmasing. Untuk akses melihat dokumen penting tersebut terbatas mulai dari Kepala Kantor Cabang Utama sampai Administrasi Kredit.

e. Di PT Bank Central Asia Tbk KCU Kalimalang sudah baik melakukan evaluasi dalam pemberian kredit. Dilihat dari pejabat yang berwenang melakukan review terhadap pemberian kredit kepada debitur. Sehingga analisa dalam proses pemberian kredit yang dilakukan account officer melewati beberapa pengecekan terlebih dahulu, agar apabila terdapat masalah di awal dapat diatasi. Serta dilakukannya evaluasi mingguan untuk memperbaiki apabila terjadi kendala pada saat proses pemberian kredit. 


\section{Informasi dan Komunikasi (Information And Communication)}

Sistem informasi dan komunikasi yang dilakukan pada PT Bank Central Asia Tbk KCU Kalimalang sudah baik, dilihat dari akses yang berupa web berisikan mengenai beberapa prosedur pemberian kredit menurut Standar Operasional Perusahaan (SOP) dan berita mengenai PT Bank Central Asia Tbk. Web tersebut yaitu www.mybca.co.id. yang hanya bisa diakses oleh karyawan - karyawan PT Bank Central Asia Tbk di seluruh Indonesia. Dalam hal pemberian kredit juga memiliki aplikasi bernama ICOS yang tentunya mempermudah account officer dalam menghitung risiko pemberian kredit. Untuk akses informasi dan komunikasi bagi pihak eksternal PT Bank Central Asia Tbk juga menyediakan web yaitu www.bca.co.id yang dapat diakses oleh semua masyarakat yang ingin mengetahui mengenai produk perbankan BCA.

5.Aktivitas Pemantauan (Monitoring Activities)

Pelaksanaan aktivitas pemantauan PT Bank Central Asia Tbk KCU Kalimalang pada proses pemberian kredit yaitu melakukan monitoring terhadap debitur yang kreditnya sudah cair, yang dilakukan oleh pihak account officer dan juga tim pengendalian kualitas kredit dan pengawasan internal cabang. Dengan kategori nasabah yang memiliki kredit lancar tidak akan dipantau, apabila debitur yang sudah memiliki kesulitan dalam pelunasan pinjaman atau kredit bermasalah, maka account officer yang bersangkutan akan terus memantau perkembangan debiturnya dan berusaha agar debitur tersebut melunasi kreditnya.

Terdapat beberapa kategori kredit bermasalah berdasarkan kolektibilitas sebagai berikut:

a. Kategori kolektibilitas 1 (satu), artinya lancer. Transaksi yang dilakukan debitur, baik itu berupa penarikan dana maupun pengembalian dana, dilakukan secara tertib, dan disiplin hingga masa jatuh tempo kredit.

b. Kategori kolektibilitas 2 (dua), artinya dalam perhatian khusus. Debitur yang tidak melakukan transaksi mulai dari sehari sebelum jatuh tempo kredit hingga 60 hari kemudian.

c. Kategori kolektibilitas 3 (tiga), artinya kurang lancer. Debitur tidak melakukan transaksi sejak 60 hari setelah jatuh tempo hingga 90 hari.

d. Kategori kolektibilitas 4 (empat), artinya diragukan. Debitur tidak melakukan transaksi sejak 90 hari setelah jatuh tempo kredit hingga 180 hari.

e. Kolektibilitas 5 (lima), artinya macet. Debitur tidak melakukan transaksi selama lebih dari 180 hari setelah jatuh tempo.

Berikut adalah hasil wawancara dengan PT Bank Central Asia Tbk KCU Kalimalang

Tabel 1 Daftar Hasil Wawancara Dengan PT Bank Central Asia Tbk KCU Kalimalang

\begin{tabular}{|l|c|c|c|}
\hline \multicolumn{1}{|c|}{ Pertanyaan } & Ya & Tidak & Keterangan \\
\hline 1. Lingkungan pengendalian & & & \\
\hline $\begin{array}{l}\text { a. Apakah perusahaan memiliki struktur } \\
\text { organisasi yang jelas mengenai pembagian tugas, } \\
\text { wewenang, dan tanggung jawab? }\end{array}$ & $\mathrm{v}$ & & \\
\hline $\begin{array}{l}\text { b. Apakah perusahaan memiliki standar etika dan } \\
\text { perilaku yang jelas dan tertulis di setiap divisi? }\end{array}$ & $\mathrm{v}$ & & \\
\hline
\end{tabular}




\begin{tabular}{|c|c|c|c|}
\hline Pertanyaan & $\mathbf{Y a}$ & Tidak & Keterangan \\
\hline $\begin{array}{l}\text { c. Apakah standar perilaku dan etika telah } \\
\text { diterapkan dengan baik? }\end{array}$ & $\mathrm{v}$ & & \\
\hline $\begin{array}{l}\text { d. Apakah karyawan terkait aktivitas pemberian } \\
\text { kredit memiliki latar belakang pendidikan yang } \\
\text { mendukung kompetensi individu? }\end{array}$ & $\mathrm{v}$ & & \\
\hline $\begin{array}{l}\text { e. Apakah perusahaan memiliki tim audit atau } \\
\text { fungsi pengawas? }\end{array}$ & $\mathrm{v}$ & & \\
\hline $\begin{array}{l}\text { f. Apakah perusahaan memberikan suatu } \\
\text { penghargaan kepada karyawan dalam } \\
\text { menyelesaikan tanggung jawabnya terhadap } \\
\text { pekerjaan? }\end{array}$ & $\mathrm{v}$ & & \\
\hline $\begin{array}{l}\text { g. Apakah perusahaan memiliki gaya operasi } \\
\text { tertentu sehingga mampu menarik nasabah dalam } \\
\text { pengambilan kredit? }\end{array}$ & $\mathrm{v}$ & & \\
\hline $\begin{array}{l}\text { h. Perusahaan memiliki kebijakan dan prosedur } \\
\text { dalam mendapatkan SDM yang kompeten }\end{array}$ & $\mathrm{v}$ & & \\
\hline $\begin{array}{l}\text { i. Perusahaan memberikan pelatihan kepada } \\
\text { karyawannya }\end{array}$ & $\mathrm{v}$ & & \\
\hline \multicolumn{4}{|l|}{ 2. Penilaian Risiko } \\
\hline $\begin{array}{l}\text { a.Apakah manajemen melakukan penaksiran } \\
\text { risiko atas kemungkinan salah saji laporan } \\
\text { keuangan atau pengambilan kredit? }\end{array}$ & $\mathrm{v}$ & & \\
\hline $\begin{array}{l}\text { b. Perusahaan memiliki komitmen untuk } \\
\text { melayani nasabah dengan baik untuk mengurang } \\
\text { risiko ekternal }\end{array}$ & $\mathrm{v}$ & & \\
\hline $\begin{array}{l}\text { c. Perusahaan sudah memiliki prosedur kerja } \\
\text { yang jelas dalam pemberian kredit sehingga tidak } \\
\text { terjadi fraud }\end{array}$ & $\mathrm{v}$ & & \\
\hline $\begin{array}{l}\text { d.Perusahaan telah menerapkan } 5 \text { C, yakni } \\
\text { watak (Character), kemampuan (Capacity), } \\
\text { modal (Capital), jaminan (Collateral), kondisi } \\
\text { ekonomi (Condition of Economy) kepada setiap } \\
\text { nasabah }\end{array}$ & $\mathrm{v}$ & & \\
\hline $\begin{array}{l}\text { e. Apakah terdapat review dari hasil analisa } \\
\text { kredit yang diajukan oleh nasabah }\end{array}$ & $\mathrm{v}$ & & \\
\hline \multicolumn{4}{|l|}{ 3. Aktivitas Pengendalian } \\
\hline $\begin{array}{l}\text { a. Perusahaan memiliki aturan dan prosedur yang } \\
\text { jelas dan tertulis mengenai syarat-syarat } \\
\text { pengajuan kredit }\end{array}$ & $\mathrm{v}$ & & \\
\hline $\begin{array}{l}\text { b. Apakah di perusahaan terdapat otorisasi proses } \\
\text { pemberian kredit yang dilakukan oleh pejabat } \\
\text { yang berwenang? }\end{array}$ & $\mathrm{v}$ & & \\
\hline $\begin{array}{l}\text { c. Apakah terdapat pemisahan fungsi dalam } \\
\text { proses pemberian kredit? }\end{array}$ & $\mathrm{v}$ & & \\
\hline
\end{tabular}




\begin{tabular}{|c|c|c|c|}
\hline Pertanyaan & $\mathbf{Y a}$ & Tidak & Keterangan \\
\hline $\begin{array}{l}\text { d. Apakah account officer memiliki fungsi } \\
\text { pemasaran hingga pemantauan? }\end{array}$ & $\mathrm{v}$ & & $\begin{array}{l}\text { Seharusnya } \\
\text { pemasaran kredit } \\
\text { dilakukan oleh } \\
\text { bagian } \\
\text { marketing dan } \\
\text { monitoring } \\
\text { dilakukan oleh } \\
\text { internal auditor } \\
\text { cabang (tidak } \\
\text { sesuai SOP) }\end{array}$ \\
\hline $\begin{array}{l}\text { e. Apakah perusahaan melakukan verifikasi } \\
\text { dokumen kredit sebelum proses kredit } \\
\text { dilakukan? }\end{array}$ & $\mathrm{v}$ & & \\
\hline $\begin{array}{l}\text { f. Apakah perusahaan melakukan evaluasi dalam } \\
\text { pemberian kredit? }\end{array}$ & $\mathrm{v}$ & & \\
\hline \multicolumn{4}{|l|}{ 4. Informasi \& Komunikasi } \\
\hline $\begin{array}{l}\text { a. Terdapat otorisasi untuk transaksi pemberian } \\
\text { kredit oleh pihak yang berkaitan }\end{array}$ & $\mathrm{v}$ & & \\
\hline $\begin{array}{l}\text { b. Terdapat komunikasi yang baik antar seluruh } \\
\text { fungsi yang terkait dengan pemberian kredit }\end{array}$ & $\mathrm{v}$ & & \\
\hline $\begin{array}{l}\text { c. Terdapat komunikasi yang baik antar } \\
\text { manajemen dan karyawan termasuk ide, saran } \\
\text { dan kritik terkait pemberian kredit }\end{array}$ & $\mathrm{v}$ & & \\
\hline $\begin{array}{l}\text { d. Apakah sistem informasi yang dilakukan telah } \\
\text { mendukung operasional dalam pengambilan } \\
\text { kredit? }\end{array}$ & $\mathrm{v}$ & & \\
\hline $\begin{array}{l}\text { e. Terdapat sistem informasi mengenai kredit } \\
\text { yang dapat diakses oleh nasabah? }\end{array}$ & $\mathrm{v}$ & & \\
\hline \multicolumn{4}{|l|}{ 5. Aktivitas Pemantauan } \\
\hline $\begin{array}{l}\text { a. Apakah dalam proses pengambilan kredit } \\
\text { account officer dan tim pengendalian kualitas } \\
\text { melakukan pemantauan terhadap kredit yang } \\
\text { diberikan kepada nasabah? }\end{array}$ & $\mathrm{v}$ & & $\begin{array}{l}\text { Monitoring } \\
\text { yang dilakukan } \\
\text { oleh account } \\
\text { officer menjadi } \\
\text { tidak benar } \\
\text { karena tugas } \\
\text { utama account } \\
\text { officer } \\
\text { menganalisis } \\
\text { kredit, tugas } \\
\text { monitoring } \\
\text { dilakukan oleh } \\
\text { internal auditor } \\
\text { cabang }\end{array}$ \\
\hline $\begin{array}{l}\text { b. Terdapat monitoring atas pemberian kredit } \\
\text { kepada nasabah }\end{array}$ & $\mathrm{v}$ & & \\
\hline
\end{tabular}




\begin{tabular}{|l|c|c|c|}
\hline \multicolumn{1}{|c|}{ Pertanyaan } & Ya & Tidak & Keterangan \\
\hline $\begin{array}{l}\text { c.Terdapat auditor internal/fungsi serupa yang } \\
\text { bertugas mengawasi dan memeriksa sistem } \\
\text { pengendalian internal secara rutin }\end{array}$ & $\mathrm{v}$ & & \\
\hline $\begin{array}{l}\text { d.Terdapat fungsi pengawas memiliki } \\
\text { kompetensi yang cukup dan bersifat objektif dan } \\
\text { independen }\end{array}$ & $\mathrm{v}$ & & \\
\hline e. Terdapat pembinaan untuk kredit yang macet & $\mathrm{v}$ & & \\
\hline
\end{tabular}

Sumber: data diolah

\section{KESIMPULAN}

Berdasarkan hasil observasi dan wawancara di PT Bank Central Asia Tbk KCU Kalimalang dalam evaluasi sistem pengendalian internal terhadap prosedur pemberian kredit dapat disimpulkan bahwa prosedur pemberian kredit pada PT Bank Central Asia Tbk sudah memenuhi standar sistem pemberian kredit dengan menerapkan analisa 5C dalam proses pemberian kredit. Sistem pengendalian internal yang diterapkan dalam pemberian kredit sudah sejalan dengan standar komponen pengendalian internal Committee of Sponsoring Organizations of the Treadway Commission (COSO) namun masih terdapat kelemahan dalam komponen aktivitas pengendalian yakni namun masih terdapat kelemahan dalam komponen aktivitas pengendalian yaitu account officer yang masih merangkap sebagai pemasaran, analisa kredit hingga pemantauan. Untuk itu sebaiknya PT Bank Central Asia Tbk KCU Kalimalang melakukan pemisahan fungsi Account Officer (AO) mulai dari pemasaran, analisa, dan pemantauan sehingga tidak terjadi kekeliruan dalam proses pemberian kredit (human error) dan tentunya proses pemberian kredit dapat berjalan dengan baik dan efektif.

\section{DAFTAR PUSTAKA}

Coso, T. C. of S. O. of the T. C. (2013). Internal control - integrated framework: executive summary. New York.

Kasmir. (2014). Bank dan Lembaga Keuangan Lainnya. In PT. Raja Grafindo Persada jakarta.

Arens, Alvin., Randal J.Elder, Mark S.Beasley. 2008. Jilid I, Edisi Ke Duabelas. Auditing dan Jasa Assurance, alih bahasa oleh Herman Wibowo. Jakarta: Erlangga

Papalangi, Riska S. (2013). Penerapan SPI Dalam Menunjang Efektivitas Pemberian Kredit UKM Pada PT BRI (Persero) Tbk Manado. Jurnal EMBA. Volume 1, Nomor 3,September 2013. Hal: 1212-1220. ISSN (Online) : 2303-1174.

Saputra. I Putu Mulyadi, Anjuman Zukhri, dan Luh Indriyani. (2014). Sistem Pengendalian Intern Pemberian Kredit Pada PT BPR Suryajaya Kubutambahan. Jurnal Pendidikan Ekonomi Undiksha. Volume 4, Nomor 1, Tahun 2014.

Muzamil, Mohammad. (2015). Analisis Penerapan Sistem Pengendalian Internal Penyaluran Kredit Pada BRI Kota Samarinda. e-Jurnal Ilmu Administrasi Bisnis. Volume 3, Nomor 3,Tahun 2015 : 661-674.

Kartika, Ismy Sentya, Ali Rasyidi, dan Mahsina. (2015). Analisis Audit Internal COSO Framework Dalam Menunjang Efektivitas Pengendalian Internal Kredit Investasi Pada PT BTN. Jurnal Akuntansi Universitas Bhayangkara Surabaya.. ISSN (Online) : 2460-7762. 


\section{JESYA}

JURNAL EKONOMI \& EKONOMI SYARIAH

Jurnal Ekonomi \& Ekonomi Syariah Vol 4 No 1, Januari 2021

E-ISSN : 2599-3410 | P-ISSN : 2614-3259

DOI : https://doi.org/10.36778/jesya.v4i1.292

Fitriamawardani Rizka. (2012). Analisa Sistem dan Prosedur Pemberian Kredit Modal

Kerja Untuk Meningkatkan Pengendalian Internal (Studi pada PT Bank Central Asia Tbk Kantor Cabang Utama Malang). Jurnal Ilmiah Universitas Brawijaya. Malang : Universitas Brawijaya. 